\title{
A new species of Cernotina (Trichoptera, Polycentropodidae) from the Atlantic Forest, Rio de Janeiro State, southeastern Brazil
}

\author{
Leandro Lourenço Dumas ${ }^{1} \&$ Jorge Luiz Nessimian ${ }^{1}$
} 1Departamento de Zoologia, Universidade Federal do Rio de Janeiro, Caixa Postal 68044, Cidade Universitária, 21941-971 Rio de Janeiro-RJ, Brasil.
dumas_bioufrj@yahoo.com.br; nessimia@acd.ufrj.br

\begin{abstract}
A new species of Cernotina (Trichoptera, Polycentropodidae) from the Atlantic Forest, Rio de Janeiro State, southeastern Brazil. Cernotina Ross, 1938, with 64 extant species, is a New World genus of caddisflies. In Brazil, there are 31 described species of which 28 are recorded from the Amazon basin. Cernotina puri sp. nov. is described and figured based on specimens collected in the Atlantic Forest, Rio de Janeiro State, Brazil. The new species can be distinguished by the shape of the intermediate appendages and tergum $\mathrm{X}$. The immature stages of $C$. puri are unknown.
\end{abstract}

KEYWORDS. Caddisflies; Cernotina puri; Neotropical Region; taxonomy.

RESUMO. Uma nova espécie de Cernotina (Trichoptera; Polycentropodidae) para Mata Atlântica, Estado do Rio de Janeiro, Sudeste do Brasil. Cernotina Ross, 1938, com 64 espécies atuais, é um gênero de tricópteros do Novo Mundo. No Brasil existem 31 espécies descritas, sendo 28 registradas para a Bacia Amazônica. Cernotina puri sp. nov. é descrita e figurada com base em exemplares coletados na Mata Atlântica, Estado do Rio de Janeiro, Brasil. A nova espécie pode ser distinguida pelo formato dos apêndices intermediários e pelo tergo X. Os estágios imaturos de C. puri não são conhecidos.

PALAVRAS-CHAVES. Cernotina puri; Região Neotropical; taxonomia; tricópteros.

Polycentropodidae is a large cosmopolitan family of caddiflies that contains about 650 extant species in 26 genera (Chamorro-Lacayo 2003; Holzenthal et al. 2007). Currently, the family is divided into two subfamilies: Kambaitipsychinae, with the single genus Kambaitipsyche Malicky, 1992, from Thailand and Burma, and Polycentropodinae, with 25 genera distributed worldwide (Holzenthal et al. 2007). Five genera occur in the Neotropics: Cernotina Ross, 1938, Cyrnellus Banks, 1913, Nyctiophylax Brauer, 1865, Polycentropus Curtis, 1835, and Polyplectropus Ulmer, 1905 (Chamorro-Lacayo 2003). The genera Antillopsyche Banks, 1941, endemic to the Greater Antillean islands, and Pseudoneureclipsis Ulmer, 1913, from the western Paleartic, Oriental, and Afrotropical regions, used to be traditionally placed in Polycentropodidae, grouped together under the subfamily Pseudoneureclipsinae (Flint 1964). Nevertheless, this subfamily was recently transferred to the family Dipseudopsidae (Li et al. 2001; Holzenthal et al. 2007). Brazil has representatives of all Neotropical genera of Polycentropodidae.

The genus Cernotina contains 64 species, exclusively New World in distribution (Santos \& Nessimian 2008). Species are found from southern Canada to central Argentina, including the West Indies. However, only a few species are recorded from North and Central America and none are known from the Chilean subregion (Flint 1983; Flint et al. 1999). The ultimate size of the genus is likely to be greatly augmented by the discovery of additional species in South America (Flint et al. 1999). In Brazil, there are 31 known species, of which
28 are recorded from the Amazon basin (Flint 1971; Sykora 1998; Paprocki et al. 2004; Santos \& Nessimian 2008). Despite the number of species already known from the country, the diversity of Brazilian Cernotina seems to be greatly underestimated.

Adults of Cernotina are commonly attracted to light traps. They are small, pale to dark brown in color, and unique in the family by the absence of a preapical foreleg spur, having a spur formula of 2-4-4 (Santos \& Nessimian 2008; Oláh \& Johanson 2010). Despite the external similarity of Cernotina species, they are easily distinguished by the male genitalic structure (Santos \& Nessimian 2008).

A new species of Cernotina was collected in the Atlantic Forest, Rio de Janeiro State. Herein, we describe and figure the male of this species. The immature stages are unknown.

\section{MATERIAL AND METHODS}

The specimens were collected with Pennsylvania light traps (Frost 1957) and conserved in 80\% ethanol. To observe genital structures, the abdomen was removed and cleared in $10 \% \mathrm{KOH}$. The illustrations were made under a stereomicroscope and a light microscope, both equipped with camera lucida. The terminology used in descriptions follows that of Holzenthal \& Almeida (2003). The type specimens are deposited in Coleção Entomológica Professor José Alfredo Pinheiro Dutra, Departamento de Zoologia, Universidade Federal do Rio de Janeiro, Brazil (DZRJ). 


\section{TAXONOMY}

\section{Cernotina puri sp. nov.}

Figs. 1-5

Description. Adult (Figs. 1-5): Forewing length: 4.0-4.3 $\mathrm{mm}(\mathrm{n}=5)$. General color, in alcohol, light yellow; head and thorax with a few pale setae; antennae stramineous; legs pale yellow, with pale brown setae; wings yellowish brown, with pale setae.

Head: Ocelli absent. Antennae about same length as forewing. Anterior setal wart oval, with few scattered setae; posterior setal warts wide, subtriangular; posterolateral setal warts large, behind eyes. Maxilary palps 5-segmented, with short, golden brown setae; segments I and II subequal in length, each much shorter than segment III; segment V extremely long, about $2 / 3$ of combined length of segments I-IV. Labial palps 3-segmented, short.

Thorax: Pronotum short, with pair of setal warts. Mesoscutum with central pair of rounded setal warts; mesoscutellum rounded, with setal punctures. Metascutellum triangular. Tibial spur formula 2-4-4. Forewings with venation typical for the genus; forks II, IV and V present; discoidal cell closed, almost same length as thyridial cell (Fig. 1A). Hindwings covered with long setae; forks II and V present; discoidal and median cells open (Fig. 1B).

Male (Figs. 2-5): Sternum IX short ventrally, with moderate U-shaped mesal incision on anterior margin; paired mesolateral ridges, with lateral projections narrow, directed posteriorly (Fig. 4). Tergum X membranous, divided mesally into 2 lobes bearing long setae (Fig. 3); in lateral view, clublike, long, with rounded apex (Fig. 2). Preanal appendages short, oblong, with long setae (Fig. 2). Intermediate appendages, in lateral view, simple, elongate, spine-like, bent, reaching apex of inferior appendages (Fig. 2); in dorsal view, curved outwards, obtusely-angled (Fig. 3). Inferior appendages, in lateral view, elongate rectangular, setose, truncate apically (Fig. 2); basodorsal lobe sclerotized, depressed, located more apically, near apicomesal lobe, apical process rounded apically and bearing 4 lateral spine-like setae on internal surface (Figs. $3,4)$; apicomesal lobe strongly sclerotized, dark, partially overlaping basodorsal lobe (Figs. 3, 4). Phallus tubular, short, with apicodorsal area depressed; internally with 2 dark spines near apex, and posteriorly with phallic sclerite formed by 2 branches that almost touch each other anteriorly (Fig. 5).

Female: Forewing length: 4.0-4.8 $\mathrm{mm}(\mathrm{n}=5)$. Color and general structure similar to male. Genitalia typical for genus.

Holotype male: BRAZIL, Rio de Janeiro: Itatiaia (Penedo, tributary of Rio Palmital, 22 $25^{\prime} 40.0^{\prime}$ 'S, 4432'46.0”W, 584 m), 10', 07.iii.2008, L.L. Dumas \& J.L. Nessimian leg. (DZRJ 2369).

Paratypes: BRAZIL, Rio de Janeiro: Itatiaia (Penedo, tributary of Rio Palmital, $22^{\circ} 25^{\prime} 40.0^{\prime}$ 'S 44³2'46.0”W, 584 m), 4 O", 07.iii.2008, L.L. Dumas \& J.L. Nessimian leg. (DZRJ 2370, DZRJ 2371, DZRJ 2372, MZSP); Itatiaia (Penedo, Rio Palmital, 22 25'02.0"S 4432'50.0”W, $689 \mathrm{~m}), 2$ O", 07.iii.2008, L.L. Dumas \& J.L. Nessimian leg. (DZRJ 2373, DZRJ 2374); Angra dos Reis (Rio Bracuí), 1 O", 11.v.2002, J.L. Nessimian leg. (DZRJ 2375); Itatiaia (Penedo, tributary of Rio Palmital, $22^{\circ} 25^{\prime} 40.0^{\prime \prime S} 44^{\circ} 32^{\prime} 46.0^{\prime \prime} \mathrm{W}, 584 \mathrm{~m}$ ), 4 ㅇ,
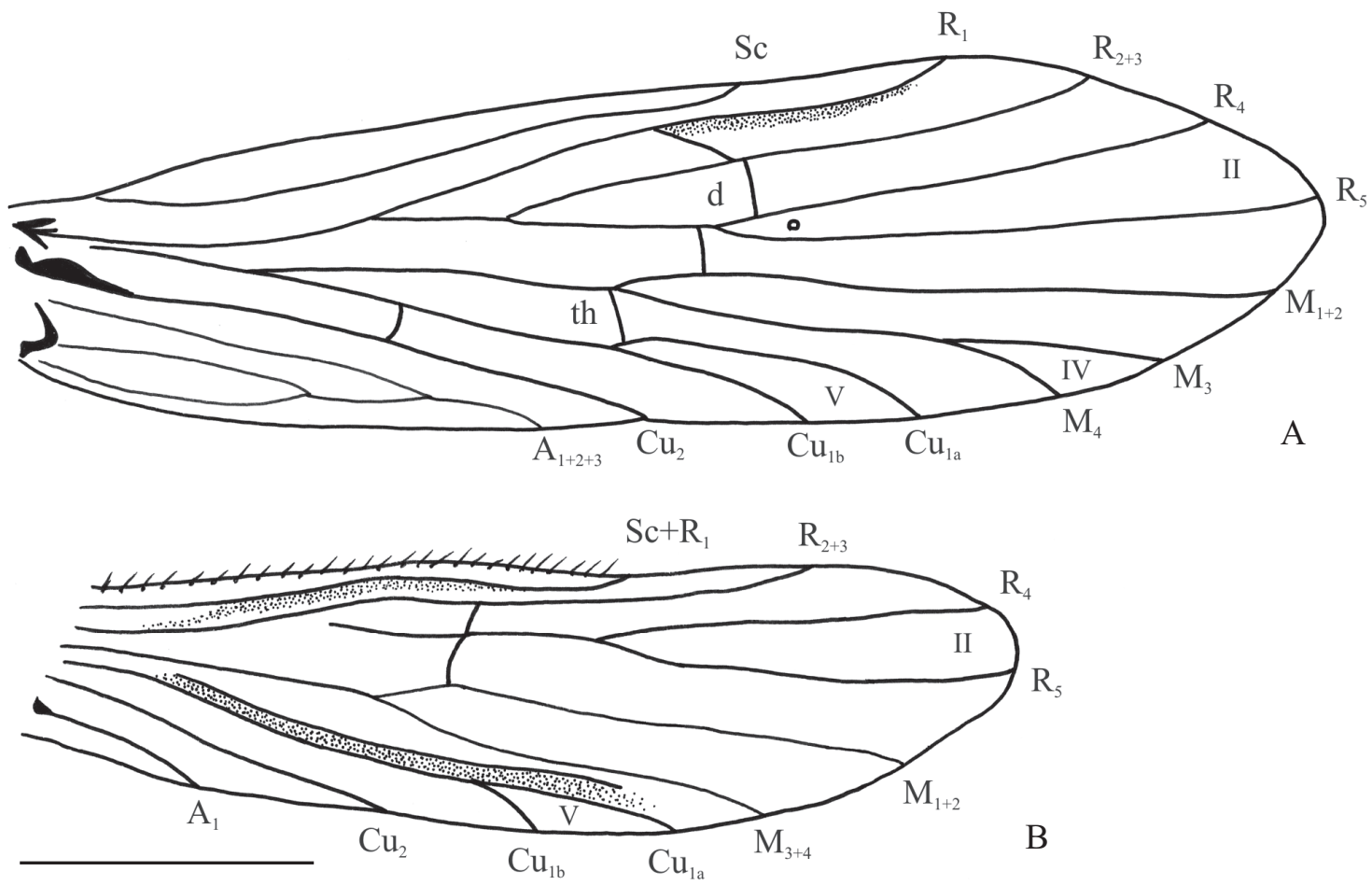

Fig. 1. Cernotina puri sp. nov., wings. 1A, Forewing; 2A, Hindwing. Abbreviations: $\mathrm{d}-$ discoidal cell; th - thyridial cell. Scale $=1 \mathrm{~mm}$. 


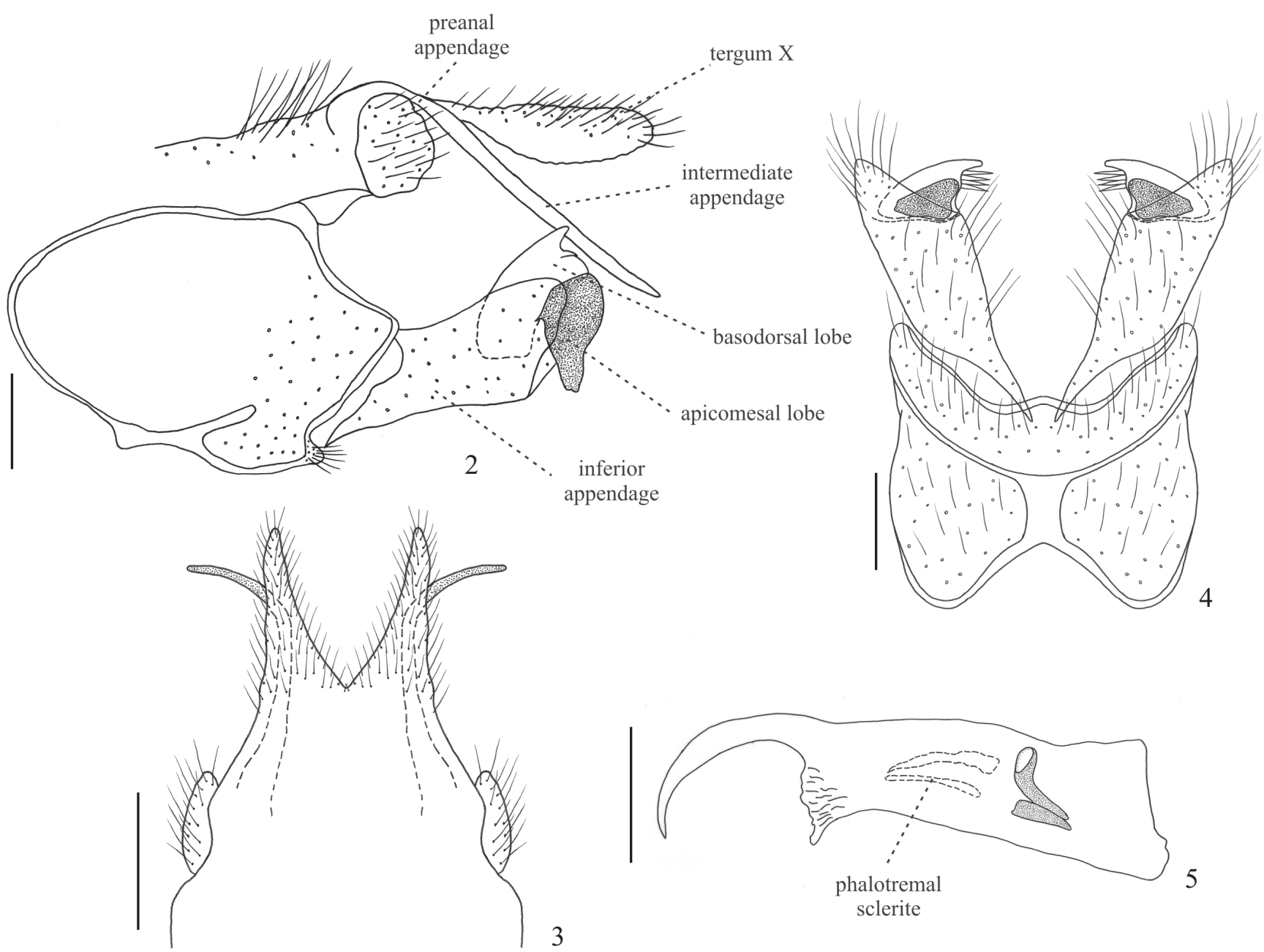

Figs. 2-5. Cernotina puri sp. nov., male. 2, Male genitalia, lateral view; 3, Tergum X and intermediate appendages, dorsal view; 4, Sternum IX and inferior appendages, ventral view; 5, Phallus, left lateral view. Scales $=0.1 \mathrm{~mm}$.

07.iii.2008, L.L. Dumas \& J.L. Nessimian leg. (DZRJ 2376, MZSP); Itatiaia (Penedo, Rio Palmital, 22 $2^{\circ} 5^{\prime} 02.0$ "S 44³2'50.0”'W, 689 m), 1 \&, 07.iii.2008, L.L. Dumas \& J.L. Nessimian leg. (DZRJ 2377); Angra dos Reis (Rio Mambucaba), 1 \&, 26.v.2002, J.L. Nessimian leg. (DZRJ 2378).

Comments. Cernotina puri sp. nov. is closely related to Cernotina filiformis Flint, 1971 and C. flexuosa Santos \& Nessimian, 2008, particulary in the shape of the bent and spine-like intermediate appendages. The new species can be distinguished by the shape of tergum $\mathrm{X}$, which is club-like and rounded apically. In the other two species, in contrast, tergum $\mathrm{X}$ tapers and is less rounded apically. An additional difference is that the basodorsal lobe of the new species is positioned apically and partially overlapped by the apicomesal lobe. Cernotina puri sp. nov. is also diagnosed by the intermediate appendages, which are bent and strongly turned ventrally, whereas in $C$. filiformis and C. flexuosa they are less bent and slightly turned upward.

Distribution. Southeastern Brazil (Rio de Janeiro State).

Etimology. This species is named in honour of the Puri Indian tribe. This extinct tribe used to inhabit the south area of Rio de Janeiro State, where the voucher specimens were collected.

\section{ACKNOWLEDGEMENTS}

We are thankful to Msc. Allan Paulo Moreira dos Santos, Dra. Daniela Maeda Takiya and two anonymous referees for comments and suggestions on this manuscript. We also thank the Instituto Brasileiro do Meio Ambiente e dos Recursos Naturais Renováveis (IBAMA) for issuing collecting permits (IBAMA 16928-1). This study was partially funded by CNPq, FAPERJ, and CAPES

\section{REFERENCES}

Chamorro-Lacayo, M. L. 2003. Seven new species of Polycentropodidae (Trichoptera) from Nicaragua and Costa Rica. Proceedings of the Entomological Society of Washington 105: 484-498.

Flint, O. S. Jr. 1964. The caddisflies (Trichoptera) of Puerto Rico. University of Puerto Rico, Agricultural Experiment Station, Technical Paper, 40: $1-80$. 
Flint, O. S. Jr. 1971. Studies of Neotropical caddis flies, XII: Rhyacophilidae, Glossosomatidae, Philopotamidae, and Psychomyiidae from the Amazon Basin (Trichoptera). Amazoniana 3: 1-67.

Flint, O. S. Jr. 1983. Studies of Neotropical caddis flies, XXXIII: New species from Austral South America (Trichoptera). Smithsonian Contributions to Zoology 377: 1-100.

Flint, O. S. Jr.; R. W. Holzenthal \& S. C. Harris. 1999. Catalog of the Neotropical Caddisflies (Insecta: Trichoptera). Columbus, Ohio Biological Survey, iv +239 p.

Frost, S. W. 1957. The Pennsylvania insect light trap. Journal of Economic Entomology 50: 287-292.

Holzenthal, R. W. \& G. L. Almeida. 2003. New species of Polycentropodidae (Trichoptera) from Southeastern Brazil. Proceedings of the Entomological Society of Washington 105: 22-29.

Holzenthal, R.W.; R. J. Blahnik; A. P. Prather \& K. M. Kjer. 2007. Order Trichoptera Kirby, 1813 (Insecta), Caddisflies, p. 639-698. In: Z. Q. Zhang \& W. A. Shear (eds.). Linnaeus Tercentenary: Progress in
Invertebrate Taxonomy. Auckland, Zootaxa 1668, $766 \mathrm{p}$

Li, Y. J.; J. C. Morse \& H. Tachet. 2001. Pseudoneureclipsina in Dipseudopsidae (Trichoptera: Hydropsychoidea), with descriptions of two new species of Pseudoneureclipsis from east Asia. Aquatic Insects 23: $107-111$.

Ólah, J. \& K. A. Johanson. 2010. Generic review of Polycentropodidae with description of 32 new species and 19 new species records from the Oriental, Australian and Afrotropical Biogeographical Regions. Zootaxa 2435: 1-63.

Paprocki, H.; R. W. Holzenthal \& R. J. Blahnik. 2004. Checklist of the Trichoptera (Insecta) of Brazil I. Biota Neotropica 4: 1-22.

Santos, A. P. M. \& J. L. Nessimian. 2008. Five new species of Cernotina Ross (Trichoptera: Polycentropodidae) from Central Amazônia, Brazil. Zootaxa 1899: 25-33.

Sykora, J. L. 1998. New species of Cernotina Ross (Insecta: Trichoptera: Polycentropodidae) from the Amazon Basin in northeastern Peru and northern Brazil. Annals of the Carnegie Museum 67: 95-104. 